\title{
LEGAL PROTECTION CARRIED OUT BY THE FINANCIAL SERVICE AUTHORITY IN A DISPUTE BETWEEN CONSUMERS AND INSURANCE COMPANIES IN INDONESIA
}

\author{
Pujiyono ${ }^{1+}$ \\ Sufmi Dasco \\ Ahmad $^{2}$
}

\author{
'Faculty of Law, Universitas Sebelas Maret, Indonesia \\ Email:pujifhuns@gmail.com \\ ${ }^{2}$ The Member of the Indonesian Parliament (House of Representatives of the \\ Republic of Indonesia)
}

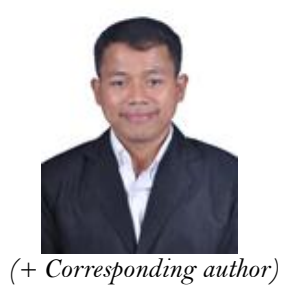

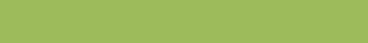

Article History

Received: 5 June 2018 Revised: 31 July 2018 Accepted: 10 September 2018 Published: 18 October 2018

Keywords
Protection
Disputes
Consumers
Insurance
Financial service authority
Settlement.

\begin{abstract}
This study aims to find out how the form of legal protection carried out by the Financial Service Authority towards consumers who experience disputes with insurance companies in Indonesia. This research is a normative legal research that is the prescriptive approach. The data are taken from secondary data types that consist of primary and secondary legal materials. Data collection techniques used are library studies, and the analytical techniques used are deductive by syllogism method. The result of the study shows that a form of repressive protections is carried out by the Financial Service Authority after a dispute between consumers and insurance services and a legal defense that contains many weaknesses. Settlement of disputes between consumers and Insurance Companies can be done through litigation/ court and nonlitigation/ out of court settlement. In the litigation process through the Commercial Court. The non-litigation process that will carried out with the institution/ internal dispute resolution step, limited facilities through mediation that facilitated by Financial Services Authority and finally through the external dispute resolution or the arbitration institution.
\end{abstract}

Contribution/ Originality: This study is one of the very few studies which have researched the form of legal protection which is provided by Financial Service Authority in the disputes between consumers and Insurance Companies so that it can provide a complete knowledge, especially for consumers who have been considered in the weak position.

\section{INTRODUCTION}

Legal protection for policyholder is an extremely important thing, because when it is related to the standard agreement practices on the insurance agreement, essentially since the signing of an insurance policy, the insured person is actually has gotten less legal protection because the content and format of the agreement are more profitable for the insurance company side (Sri, 2001). The position inequality between the insurance policyholder and the insurance company as well as in applying the standard agreement makes the function of legal protection for the insurance policyholder is questioned. One of the institutions which has authority and function in giving this 
legal protection is Otoritas Jasa Keuangan/OJK (Financial Service Authority), as well as being regulated in Regulation Number 21 of 2011, which in Article 55(1) states that: "Since $31^{\text {st }}$ December 2012, the functions, duties, and authorities of regulating and monitoring the financial service activities in capital market sector, insurance, pension fund, financial institution, and other financial service institutions are changes from the Minister of Finance and the Capital Market Supervisory Body and Financial Institutions to OJK (Abdulkadir, 2011).

Insurance Companies do not always work smoothly (Fransiska, 2012). Anytime, these companies may get bankruptcy if the management of these insurance companies does not work properly. Thus, it needs a certain management which can manage or process the insurance companies' wealth properly. A bankrupt insurance company will experience a deterioration and limitedness on its business so that it may harm the consumers of this insurance service (A Junaedy Ganie, 2010). Because the presence of loss which can be experienced by the consumers of insurance service, those consumers have the right of getting legal protection (Sufmi and Aldyan, 2017).

Based on the above explanation, the researchers are interested in studying the form of legal protection which is provided by OJK in the disputes between consumers and Insurance Companies.

\section{RESEARCH METHODOLOGY}

The kind of legal research used in this legal writing is normative legal research, or also called with doctrinal legal research. In this study, the writer uses the statue approach. The statue approach is carried out by reviewing all Statues and regulation related to the handled legal issues. The legal material which is used is primary legal material that is the applied Statue, and secondary legal materials. Mant regulations are used for primary data, such as : Law Number 21 of 2011 concerning the Financial Services Authority, Law Number 8 of 1999 concerning Consumer Protection, Law Number 30 of 1999 concerning Arbitration and Alternative Dispute Settlement, Financial Services Authority Regulation Number 1 of 2013 concerning Consumer Protection in the Financial Services Sector, Financial Services Authority Regulation Number 1 of 2014 concerning Alternative Institutions for Settlement of Financial Services Disputes. The collecting technique of the legal material in this study is a documentary study method or related literature material. The data are analyzed by syllogism deductive (Peter, 2014).

\section{RESULT OF THE RESEARCH AND DISCUSSION}

According to Article 1 of General Provision of Regulation of OJK, someone who is called with Consumer is the party who places his fund and/ or utilizes some services provided by the Financial Services Institution, such as the consumers on Banking, the financiers on Capital Market, the policyholders in Insurance, and the participants on Pension Fund, based on the legislation in the financial service sector. The definition of policyholder itself is regulated on the Article 1 of the General Provision of Regulation number 40 of 2014 on Insurance where the Policyholder is the party who binding himself based on an agreement with an Insurance Company, Sharia Insurance Company, Reinsurance Company, or Sharia Reinsurance Company in order to get a protection or management upon some risks for himself, the insured person, or other participants.

At the time of dispute appears between the policyholders and the insurance company, in accordance to its function, duty, and authority, OJK is carrying out a protection to the consumers and society, which is arranged in Article 29 and Article 30 of Regulation of OJK. Article 29 and Article 30 of Regulation of the Financial Services Authority is a representation of kinds of protection which is provided by Financial Services Authority after the disputes occur or in other words, a repressive protection.

Through Article 2 (2) of the Regulation of Financial Services Authority Number 1 of 2014 on the Alternative Institutions of Disputes Resolution in Financial Services Sector, if there is not any agreement achieved in the costumers' complaints Resolution by the Financial Services Authority, so that the consumers can carry out the disputes resolution outside of the court (non-litigation) or through the court (litigation). Resolving a dispute through a court is carried out by registering an accusation to the commercial court. 
Article 29 of the Regulation of Financial Services Authority is carrying out the consumers' complaint services, including:

1) Preparing some adequate devices for the complaint services of the injured consumers by a performer in the Financial Services Institution;

2) Making a mechanism complaints of the injured consumers by the performer in the Financial Services Institution;

3) Facilitating complaint resolving of the injured consumers by the performer in the Financial Services Institutions in accordance with legislation in the financial service sector.

A complaint is consumers' dissatisfaction expression which is caused by the presence of loss and/ or potential financial loss on the consumer, Zaini (2017) which is suspected because of the mistake or negligence of the Financial Services Institution, in this case the Financial Services Institution is Insurance Company, by the presence of this complaint, the insurance company is required to serve and solve the complaint before the complaint is delivered to other parties. This insurance company is required to immediately follow up and resolve the complaint no later than 20 (twenty) days of the workdays after the date of complaint submission, or in a particular condition, the Insurance Company can extend the period until the next 20 (twenty) days. These special conditions are:

1) The Financial Services Institution which accepts the complaint is different with the Financial Services Institution where the complained issue happened and there is some communication constraint among the two Financial Services Institutions.

2) The financial transaction complained by the consumers need special attention to the documents of the Financial Services Institution; and/ or

3) There are other things outside the control of theFinancial Services Institution, including the presence of the third party's involvement outside the Financial Services Institution in the financial transaction which is done by the consumers.

The extra time for resolving the complaint as mentioned has to be informed in write to the consumers who have submitted the complaint before the date expires (Ema and Rai, 2016).

In performing its activities, the Financial Services Institution should have a procedure of services and complaints resolution which at least contains the following:

1) The application of the principles of Accessibility, Independency, Equality, Efficiency, and effectiveness;

2) The execution of consumers' complaint submission is carried out in various ways, including face to face communication, e-mail, and mail, but it is not included some complaints which are performed through a reporting on mass media;

3) The Financial Services Institution is required to immediately follow up and resolve the complaints as late as 20 (twenty) work days;

4) In a certain condition, the Financial Services Institution is able to extend the deadline until the next 20 (twenty) work days;

5) The communication procedure to the consumers insufficiently covers the services and complaint resolution procedure in a more understandable and easier to be accessed by the consumers and a resolution offering if from the analysis and evaluation carried out by the Financial Services Institution it is found that the presence of the complaint is caused by the mistake of this Financial Services Institution itself.

6) To conceal some information related to consumers who have submitted some complaints to any parties, except the Financial Services Authority, in order to the complaint resolution, is required by the legislation and/ or upon the approval of the consumers.

The Financial Services Institution is required to give some services and complaint resolution, with some provisions, including giving a balanced and objective treatment to each complaint, giving the consumers an 
adequate opportunity to explain the complaint material and also giving other parties an opportunity to give some explanation in resolving the complaint (Tax and Brown, 1998). During the process of complaint, the Financial Services Institution is forbidden to collect some cost upon the services and complaint resolution.

The follow up for the consumers' complaint through the alternative institutions is necessarily able to be performed. There are some steps which have to be taken by the consumers, the first is, the consumer party can submit a claim to the Financial Services Institution party through its work unit or the complaint handling function which is established by each Financial Services Institution which is specifically used in handling the consumers' complaint with some requirements at least there is an agreement suitability, there is some material loss, it is related to financial aspect, and in a condition where the consumer has fulfilled his obligations to the Financial Services Institution party.

Related to the process, the Financial Services Institution party can perform a complaint resolution in the form of apology or offering some compensation (redress/ remedy) if the consumers' complaint is valid.Specifically for the compensation, it is able to be performed if the loss experienced by the consumers happened because of the financial aspect. If the consumers and the Financial Services Institution agree, thus the consumers are not allowed to carry out some advanced legal effort. Meanwhile, if there is not an agreement, the consumers and the Financial Services Institution can bring the dispute resolution to the next step that is through Financial Services Authority (OJK) or Alternative Dispute Resolution Institution.

Based on the Form Letter of the Financial Services Authority Number 2/SEOJK.07/2014, disputes resolution can be done in two ways, including:

1) Complaint resolution in the form of apology or offering some compensation (redress/ remedy);

2) Complaint resolution through alternative institution for dispute resolution.

The Financial Services Institution, in this case, the Insurance Company, can perform the complaint resolution in the form of apology or offering some compensation to the consumers with some provisions, including:

1) Remembering that "apology" is an act of both parties between the Financial Services Institution and the Consumers, the procedures in expressing this "apology" is made based on the agreement. If there is not any agreement between the Financial Services Institution and the Consumers, the "apology" is performed in writing.

2) The loss that can receive some compensation is a loss which occurs because of some financial aspects. The intended compensation should fulfill the following requirements:

a) There is a complaint which contains compensation claim which is related to financial aspects;

b) The submitted consumers' complaint is correct after the Financial Services Institution is doing some research;

c) There is some discrepancy between the product agreement and/ or services with the received products and/ or services;

d) There is some material loss;

e) The consumers have fulfilled their obligations.

3) The mechanism of compensation submission should fulfill some requirements as follow:

a) Submitting a compensation application which is accompanied by the chronology of events that the explanation about the product and/ or service utilization which is not appropriate should be accompanied with some evidence;

b) The application should be submitted maximum until 30 (thirty) days after some products and/ or services which are not appropriate are found;

c) The application is submitted in an application letter and can be represented by enclosing a procuration; 
d) The compensation is only for something which gives direct impacts to the consumers and maximum as much as the loss value experienced by the consumers.

If through an Internal Dispute Resolution step there is not any consensus achieved, so the second step is limited facility by OJK (Pujiyono and Laksmitasari, 2017). A step that should be taken by the consumers at this stage is completing a number of documents, including written application which contains the chronology and some claim-supporting documents, personal identity evidence, reporting evidence that he has gone to PUJK, and also a statement letter that explains that the dispute is not in judicial process or other dispute resolution institutions.

OJK itself opens five lanes as the means of communication with the consumers that is through a letter which is submitted to the Members of Commissioners Board of Education and Consumers Protection of OJK sector, a website of sikapiuangmu.ojk.go.id, e-mail, fax, and phone at 150065. Besides that, the other requirement that should be noticed is financial loss made by the Financial Services Institution, especially for banking, capital market, pension fund, life insurance, financing, mortgage companies or guarantee sectors maximum 500 million rupiahs.

While, especially for the loss in public insurance sector the maximum cost is 750 million rupiah. If it has been appropriate with the requirements asked by OJK, the next step is the OJK party will designate a facilitator to resolve the complaint. Next, the consumers together with the Financial Services Institution should agree to the facility agreement from the OJK, which basically it is an agreement of both sides to be obedient and submissive to the facility rules established by the OJK.

As late as 30 work days after the facility agreement is signed, the dispute resolution between the consumer and the Financial Service Institution should achieve a result. If it is necessary to get an additional time, there is an opportunity of extra time during the next 30 work days, which is accounted after the first period has finished. From the result limited facility, evidently both the sides are agreed so that the agreement is poured into an agreement deed which is signed by the consumer and the Financial Services Institution. If there is not an agreement in the limited facility by the OJK, the consumer can submit a resolution through Alternative Dispute Resolution Institution.

The resolution through Alternative Dispute Resolution Institution is the final step the consumers can take if they want to resolve the disputes outside the court. The process in Alternative Dispute Resolution Institution itself can be taken through three lanes: mediation, adjudication, or arbitration. But, the consumers can not directly take adjudication and arbitration if they previously have not taken mediation process yet. The first thing that should be done by the consumers is submitting the dispute resolution application to the independent institution which has been registered in Alternative Dispute Resolution Institution and supervised by the OJK.

The completeness of the document which is needed is not far different with documents which are included in the previous two steps. Next, the institution party will carry out verification and give a confirmation in the form of an acceptance of dispute resolution application. Then, it comes into an examination stage of dispute substance submitted by the consumers. In the mediation stage, either consumers or Financial Services Institution together designate and decide their own mediator.

At this mediation stage, the mediator is only facilitating and attempting a reconciliation between the two parties. Then, the parties themselves will make an agreement to reconcile which is then poured into a reconciliation deed. If it has not been a success, the consumers still have one final step which can be taken, adjudication and arbitration. The thing that has to be remembered is that, at this stage either adjudicator or arbitrator, both of them have authority to make a decision. The difference is that adjudication effort can be taken if the submitted claim value belongs to the small and retail group. While the arbitration can be taken if the claim value is big and the complexity level of the disputes is categorized complicated. For the cost, the resolution through Alternative Dispute Resolution Institution for small amount of financial claim value where each Alternative Dispute Resolution Institution institution has its own value of magnitude is free. But, the OJK side itself claims that the cost charged is not expensive (Sembiring, 2011). 
A real step performed by the OJK as a kind of legal protection to the consumers is by a submission of bankruptcy application to PT. BumiAsih Jaya. PT. BumiAsih Jaya is a local life insurance company that has established since 1967 and has thousands of consumers of policyholders all over Indonesia, but since 2009 this company had been experiencing a failure in managing its financial health, thus the Commissioner Board of OJK released a decision Number: KEP - 112/d.05/2013 on $18^{\text {th }}$ October 2013 on the revocation of business permit in life insurance business field on behalf of PT. Asuransi Jiwa Bumi Asih Jaya. Based on the revocation of Business permit, PT. Asuransi Jiwa Bumi Asih Jaya should fulfill its obligations to every policyholder but PT. Asuransi Jiwa Bumi Asih should submit a decision revocation application Number: KEP - 112/d.05/20130) by OJK in Administrative Court with a rejected verdict. PT Asuransi Jiwa Bumi Asih Jaya has not implemented this verdict so that the OJK submits a bankruptcy claim to PT Asuransi Jiwa Bumi Asih Jaya in order to protect the creditors' interest (the policyholder) through the commercial court of Central Jakarta.

The verdict of Jakarta Commercial Court Number 04/Pdt.SUS-Pailit/2015 PN.Niaga.JktPst. Jo Number 27/PDT.DUD.PKPU/2015/PN.Niaga.JktPst. The panel of judges decided to reject all the bankruptcy applications of PT. AsuransiJiwaBumiAsih Jaya which is submitted by the OJK. OJK in performing its duties and authority in protecting public interest submits a cassation request with the verdict Number. 408K/PDT.SUS.Pailit/ 2015 as a continued effort from the verdict of bankruptcy refusal in the Commercial Court and it is granted. This bankruptcy verdict gives some impacts either to the debtors or creditors (the policyhoders).

OJK legal consideration in submitting bankruptcy application on behalf of PT Asuransi Jiwa Bumi Asih Jaya has been appropriate to OJK's duties and authority in protecting the creditors' interest (the policyholder), including:

1) Based on Article 19 of Regulation Number 40 of 2014 on Insurance, PT. Asuransi Jiwa Bumi Asih Jaya does not fulfill the provision of financial health, so that it is not able to fulfill the claim or other obligations which arise because of the policy and experiencing a reduction on its financial health.

2) Based on the provision of Article 41 (2) of Government Regulation Number 73 year 1992 on Insurance Business Management, the OJK gives a warning to PT. Asuransi Jiwa Bumi Asih Jaya in the form of administrative sanction which belongs to OJK's authority.

3) Article 2 (5) Regulation Number 37 year 2004 on Bankruptcy and Postponement of Debt Payment Obligations, in this case the debtor is insurance company, the application of bankruptcy statement can only be submitted by the Minister of Finance.

4) Article 55 (1) Regulation of OJK states that the duties and authorities of the Minister of Finance change to OJK, so that the application of bankruptcy statement of PT. Asuransi Jiwa Bumi Asih Jaya is performed by the OJK.

\section{CONCLUSION}

Protection by the OJK to the consumers who are experiencing disputes with insurance companies is carried out through litigation and non-litigation ways, where Alternative Dispute Resolution Institution as an arbitration institution actually has not had its own procedural law. Alternative Dispute Resolution Institution as an institution for dispute resolution, is required to have its own procedural law (procedure) as a mechanism in resolving a dispute which should be arranged decisively, systematically, clearly, and fulfilling the compulsory principles, including accessibility, independency, equality, efficiency, and effectiveness principles.

Funding: This study received no specific financial support.

Competing Interests: The authors declare that they have no competing interests.

Contributors/Acknowledgement: Both authors contributed equally to the conception and design of the study. 


\section{REFERENCES}

A Junaedy Ganie, 2010. Indonesian insurance law. Jakarta: Sinar Grafika.

Abdulkadir, M., 2011. Indonesian insurance law. Bandung, PT: Citra Aditya Bakti.

Ema, R. and M. Rai, 2016. Dispute resolution through an alternative institution for dispute settlement in the financial services sector. Journal of Padjajaran Law Science, 3(2): 242.

Fransiska, A.I., 2012. Observing the gap of independence of the FSA in the FSA law. Banking and Central Banking Law Bulletin, $10(1): 53$.

Peter, M.M., 2014. Legal research. Jakarta: Kencana Prenada Media Group. pp: 55-108.

Pujiyono, W., J. and K. Laksmitasari, 2017. The effectiveness of customer complaint resolution facilitation program by financial service authority. International Journal of Economic Research, 14(5): 71-86.

Sembiring, J.J., 2011. How to resolve disputes out of the court. Jakarta: Visimedia. pp: 32-34.

Sri, R.H., 2001. Insurance law and insurance company. Jakarta: Sinar Grafika.

Sufmi, D.A. and A. Aldyan, 2017. A criminological review on' cornering the market' practice in securities trading in capital market (a Study in Indonesia). Journal of Advanced Research in Law and Economics, 8(7 (29)): 2263-2267.Available at: https://doi.org/10.18535/ijmei/v4i1.07.

Tax, S. and S. Brown, 1998. Customer evaluations of service complaint experiences. Journal of Marketing, 62(2): 60-76.Available at: https://doi.org/10.2307/1252161.

Zaini, Z.D., 2017. The function of financial services authority (FSA) in dispute settlement banking customers in Indonesia. European Research Studies Journal, 20(3A): 69-81. 